Vol. 9 (2000): 121-134.

\title{
Timing of primary growth harvest affects the yield and nutritive value of timothy-red clover mixtures
}

\author{
Marketta Rinne \\ Agricultural Research Centre of Finland, Animal Production Research, FIN-31600 Jokioinen, Finland, \\ e-mail:marketta.rinne@mtt.fi \\ Arja Nykänen \\ Agricultural Research Centre of Finland, Resource Management Research, FIN-51900 Juva, Finland, \\ e-mail:arja.nykanen@mtt.fi
}

\begin{abstract}
The effects of partition of growth time between primary growth and regrowth of perennial organically grown mixed (mainly timothy and red clover) leys were studied over two years in Juva, Finland. Primary growth was harvested at three different dates and regrowth on a single occasion from all plots. Dry matter (DM) yield of primary growth increased by $116 \mathrm{~kg}$ per ha per day by delaying harvest $(\mathrm{P}<0.001)$ which was partly compensated by a reciprocal effect in the regrowth. Harvesting schedules had no effect on the botanical composition of herbage within harvests, but the proportion of red clover was lower in the primary growth $(0.28)$ than in the regrowth $(0.71)$. The proportion of red clover in weighted total yield decreased linearly from 0.46 to $0.35(\mathrm{P}<0.01)$ by delaying the primary growth harvest.

The nutritional quality of timothy and red clover declined with advances in primary growth, the extent of which was greater for timothy. Digestible organic matter content in DM (D-value) decreased 2.6 and $5.6 \mathrm{~g} / \mathrm{kg}$ per day in red clover and timothy, respectively. Reciprocal effects were observed in regrowth. However, the total yield and quality from both harvests was strongly influenced by primary growth, since it accounted for on average 0.68 of total yield and differences in the nutritional quality of regrowth were smaller than for primary growth.
\end{abstract}

Key words: botanical composition, chemical composition, digestibility, growth stages, maturity, morphology, Phleum pratense, Trifolium pratense

\section{Introduction}

Use of forages for animal production is dependent on attaining a high dry matter (DM) yield and maximising forage nutritional quality. Since these primary factors are in direct conflict, forage production is essentially a compromise between yield and quality. It is well documented that increases in DM yield of primary growth are accompanied by a decrease in herbage digestibility and nutrient concentrations (see Van 


\section{AGRICULTURAL AND FOOD SCIENCE IN FINLAND}

Rinne, M. \& Nykänen, A. Effects of harvesting strategy on organically grown leys

Soest 1994). Forage digestibility has a profound effect on animal production. Based on 8 studies, milk production of cows fed grass silage based diets was reported by Huhtanen (1994) to decrease on average by $0.26 \mathrm{~kg} /$ day for each incremental $10 \mathrm{~g} / \mathrm{kg}$ decline of digestible organic matter (OM) content in DM (D-value).

Regulations on organic production require that forages comprise 0.60 of daily DM consumption of cattle ( 0.50 is acceptable for 3 months at the beginning of lactation) and the feeds should preferably be produced at the same farm where they are used (European Union 1999). This places restrictions on the use of concentrate feeds to compensate for sub-optimal forage quality or quantity which may lead to substantial losses in milk production. Thus, implementation of an optimal harvesting strategy is even more important for organic than conventional farming.

Forage leys are harvested several times during the growing season and therefore studies concentrating only on primary growth are inadequate. Under Finnish climatic conditions, typically only two or occasionally three cuts of grass can be harvested within a year. For mixed leys containing clover, such as organically grown leys, generally only two harvests are obtained. The development of leys is slower in regrowth compared to primary growth (Syrjälä and Ojala 1978, Pulli 1980, Huokuna and Hakkola 1984, Bélanger and McQueen 1998, 1999), but the residual effects of primary cutting date on subsequent harvest(s) must also be considered. Studies where the growing time has been differentially allocated between primary growth and regrowth are limited. This approach is however, relevant at the farm level, because the harvest of regrowth under Finnish conditions is often optimized based on overwintering ability of the leys rather than forage quality.

Forage legumes are essential components of organic production. The biological nitrogen $(\mathrm{N})$ fixation ability of Rhizobium-bacteria in symbiosis with legume roots is the basis of $\mathrm{N}$ supply to the farm nutrient cycle. Legumes (in Finnish conditions mainly red clover) are usually grown as mixtures with grasses, but the different characteristics of legumes and grasses further complicate the choice of harvesting strategy.

The current experiment was designed to elucidate the effects of partition of growth time in a two-cut system on forage quantity and quality. Perennial grass-clover leys were managed under organic conditions, but results may also be applicable to conventional forage production practises. Direct comparisons between organic and conventional leys in relation to forage production were not found and may be difficult to interpret, since the differences in farming systems are likely to affect forage production through changes in, for example, soil $\mathrm{N}$ status and the proportion of different plant species. The mutual dynamics and individual properties of two important plant species, timothy and red clover, grown as a mixed sward, were evaluated. Timothy and red clover are usually grown for animal feeds, and therefore results are discussed in context to animal production. Preliminary results from the first year of the study have previously been presented (Rinne et al. 1996).

\section{Material and methods}

Leys were grown under organic conditions at Partala Research Station $\left(62^{\circ} \mathrm{N}\right)$ of the Agricultural Research Centre of Finland on fine sand moraine soil (3-6\% OM, $\left.\mathrm{pH}_{\left(\mathrm{CaCl}_{2}\right)} 6.3-6.8\right)$. The seed mixture was comprised of timothy (Phleum pratense cv. Bottnia 2; $10 \mathrm{~kg} / \mathrm{ha}$ ), meadow fescue (Festuca pratensis cv. Kalevi; 6 kg/ha) and red clover (Trifolium pratense cv. Bjursele; $4 \mathrm{~kg} / \mathrm{ha}$ ). In 1995, two main plots (one and two year old leys) were used. The same plots were utilized the following year with an additional main plot of a one year old ley. The plots utilized in the present experiment were part of a larger experiment described by Nykänen et al. (2000).

Partition of growth time between primary growth and regrowth was studied in a two-cut 
Vol. 9 (2000): 121-134.

Table 1. Cutting dates and description of growing seasons.

\begin{tabular}{|c|c|c|c|c|c|c|c|c|}
\hline & \multicolumn{4}{|c|}{1995} & \multicolumn{4}{|c|}{1996} \\
\hline & Date & Days ${ }^{1)}$ & $\mathrm{CT}^{1,2)}$ & $\mathrm{CR}^{1,3)}$ & Date & Days & $\mathrm{CT}$ & CR \\
\hline \multicolumn{9}{|c|}{ Primary growth } \\
\hline $\mathrm{I}^{4)}$ & 13 June & 28 & 316 & 29 & 17 June & 48 & 245 & 78 \\
\hline II & 21 June & 36 & 410 & 49 & 26 June & 57 & 308 & 103 \\
\hline III & 29 June & 44 & 496 & 52 & 8 July & 69 & 408 & 151 \\
\hline \multicolumn{9}{|c|}{ Regrowth } \\
\hline I & 28 August & 77 & 790 & 114 & 19 August & 64 & 582 & 156 \\
\hline II & 28 August & 69 & 694 & 96 & 19 August & 55 & 521 & 131 \\
\hline III & 28 August & 61 & 604 & 91 & 19 August & 43 & 424 & 83 \\
\hline
\end{tabular}

1) Cumulated since the onset of growth in the spring for primary growth, and since the harvest of primary growth for regrowth

2) Mean daily temperature $-5^{\circ} \mathrm{C}$

3) Rainfall (mm)

4) I, II and III refer to the order of cutting dates in the primary growth

system. Main plots were divided into three subplots $\left(10 \mathrm{~m}^{2}\right)$ which were harvested at three different dates in primary growth, each with three replicates. Regrowth was simultaneously harvested from all plots (Table 1). For maximal utilization of the growing season, regrowths were harvested at the end of August, a time considered optimal for overwintering of the leys.

Plots were harvested with an experimental grass plot harvester, grass yield was measured, and representative samples were collected for laboratory analysis. Samples were dried at $105^{\circ} \mathrm{C}$ for $20 \mathrm{~h}$ for DM determination. Botanical composition of the samples was determined from a representative sample weighing at least $0.5 \mathrm{~kg}$. After botanical separation, the main species, timothy and red clover were fractionated into leaves, stems and inflorescenses. Leaf sheaths in timothy and leaf stalks in red clover were included in the stem fraction. Botanical and morphological fractions were dried in $60^{\circ} \mathrm{C}$ until dry to calculate their proportions on a DM basis. Then the leaf and stem fractions of timothy and red clover from the three replicates were combined for subsequent analysis.

The ash content of the leaves and stems was determined in a muffle furnace at $550^{\circ} \mathrm{C}$ for $6 \mathrm{~h}$.
Total $\mathrm{N}$ content was measured by the Dumas method using a Leco FP-428 $\mathrm{N}$ analyzer and crude protein $(\mathrm{CP})$ content was calculated as 6.25 $\times N$. Neutral detergent fibre (NDF) was determined according to Robertson and Van Soest (1981) and in vitro OM digestibility assessed by cellulase solubility (Friedel 1990).

D-value was calculated as (1000 - ash content $) \times \mathrm{OM}$ digestibility and the metabolizable energy (ME) content of the fractions as 0.0169 $\times$ D-value -1.05 (MAFF 1975). The value of dietary protein defined as amino acids absorbed from the small intestine (AAT) and protein balance in the rumen (PBV) were calculated according to the Finnish protein evaluation system (Madsen et al. 1995, Tuori et al. 1996). An effective rumen degradability of protein of 0.75 was assumed for all samples. Digestible crude carbohydrate content was calculated as (1000 ash content - CP content - ether extract content) $\times$ OM digestibility. Ether extract content was not determined, but values of 20 and $30 \mathrm{~g} / \mathrm{kg}$ DM were assumed for timothy and red clover fractions, respectively. No corrections in AAT values were made for negative PBV values. Composition of whole plants was reconstituted neglecting the contribution of inflorescenses, and 


\section{AGRICULTURAL AND FOOD SCIENCE IN FINLAND}

Rinne, M. \& Nykänen, A. Effects of harvesting strategy on organically grown leys

the composition of total yield neglecting the contribution of other plant species, since these were not determined.

Rate of digestion $\left(\mathrm{k}_{\mathrm{d}}\right)$ in the rumen was measured using a modified in vitro method of Theodorou et al. (1994). Only samples from 1995 were analysed. Duplicate samples of $0.5 \mathrm{~g}$ were incubated in gas tight culture bottles with rumen fluid and buffers. The volume of gas produced by bacterial fermentation was measured manually with a syringe at $3-12 \mathrm{~h}$ intervals, for a minimum of 11 times over a period of $3 \mathrm{~d}$. The curve of cumulative gas production was fitted to the equation $\mathrm{p}=\mathrm{a}+\mathrm{b}\left(1-\mathrm{e}^{-\mathrm{ct}}\right)$ (Ørskov and McDonald 1979), where $a+b$ represents the cumulative gas production and $\mathrm{c}$ the rate of digestion. The cumulative gas production was not used to assess forage quality, because the volume of gas is greatly influenced by the chemical composition of the substrate (fermentation of $\mathrm{CP}$ produces less gas than fermentation of carbohydrates) and the proportion of different fermentation gases.

The cumulative temperature from the onset of growth in the spring [ $\Sigma$ (mean daily temperature $\left.-5^{\circ} \mathrm{C}\right)$ ] is based on data collected from the nearby Finnish Meteorological Institute in Mikkeli, $40 \mathrm{~km}$ south west from the experimental site. The onset of growth starts when the mean daily temperature rises above $5^{\circ} \mathrm{C}$ for 5 consecutive days. Rainfall was measured at the experimental site (Table 1).

Numerical values for daily changes of different parameters were calculated according to linear regression equations. Experimental data was subjected to analysis of variance using the GLM procedure of SAS using the following model:

$y_{i j k l}=\mu+Y_{i}+A_{j}+C_{k}+R_{l}+e_{i j k l}$,

where $Y$ is the year (1-2), $A$ is the age of the ley (1-3), $C$ is the cutting time of primary growth $(1-3)$ and $R$ is the replicate (1-3). Primary growth, regrowth and total yield accross both harvests were analysed separately. Some interactions of "year $\times$ cutting time" and "age of the ley $\times$ cutting time" were found, but because these were in parameters of minor interest, they were not included in the final model. To study the effect of "age of the ley" results were analysed separately for both years. Data concerning herbage chemical composition was not subjected to statistical analysis because replicates were combined. The focus of this experiment was on harvesting strategies and the results of "year" and "age of the ley" are not tabulated. Sums of squares for the effect of "cutting time of primary growth" were separated using orthogonal contrasts into single degree of freedom comparisons of linear $\left(\mathrm{P}_{\mathrm{L}}\right)$ and quadratic $\left(\mathrm{P}_{\mathrm{Q}}\right)$ trends.

\section{Results}

Postponing the harvest of primary growth increased DM yield of the leys $\left(\mathrm{P}_{\mathrm{L}}<0.001\right)$, but an opposite trend in the regrowth $\left(\mathrm{P}_{\mathrm{L}}<0.001\right)$ partially compensated for this response resulting in a markedly lower though significant $\left(\mathrm{P}_{\mathrm{L}}<0.05\right)$ effect in total DM yield (Table 2). The increase in DM yield of primary growth was $116 \mathrm{~kg}$ per ha per day when the harvest was postponed, but the decrease in regrowth was $79 \mathrm{~kg}$ such that the effect of timing of first cut on total yield was 37 $\mathrm{kg}$ per day per ha. Yields of digestible OM, ME and CP in primary growth and regrowth behaved similarly as DM yield except that no significant effects for total yield were found ( $\mathrm{P}>0.05)$.

The total DM yield was higher in 1995 than in 1996 (6011 vs. $5012 \mathrm{~kg}, \mathrm{P}<0.001)$. In 1995, the proportion of primary growth was 0.73 of the total yield, while in 1996 it was 0.64. In general, the plants were in a later stage of development in 1995 than in 1996 during harvests of primary growth (lower proportion of leaves and D-value) despite earlier harvesting dates.

In 1995 the one year old leys were less productive than two year old ones (5652 vs. 6370 kg DM; P<0.05). In 1996, the total DM yields for one, two and three year old leys were 4301, 5275 and $5461 \mathrm{~kg}$, respectively $\left(\mathrm{P}_{\mathrm{L}}<0.01\right)$.

Postponing the harvest of primary growth did 
Vol. 9 (2000): 121-134.

Table 2. The effect of partition of growth time on DM, digestible organic matter, metabolizable energy and crude protein yields of organically grown leys.

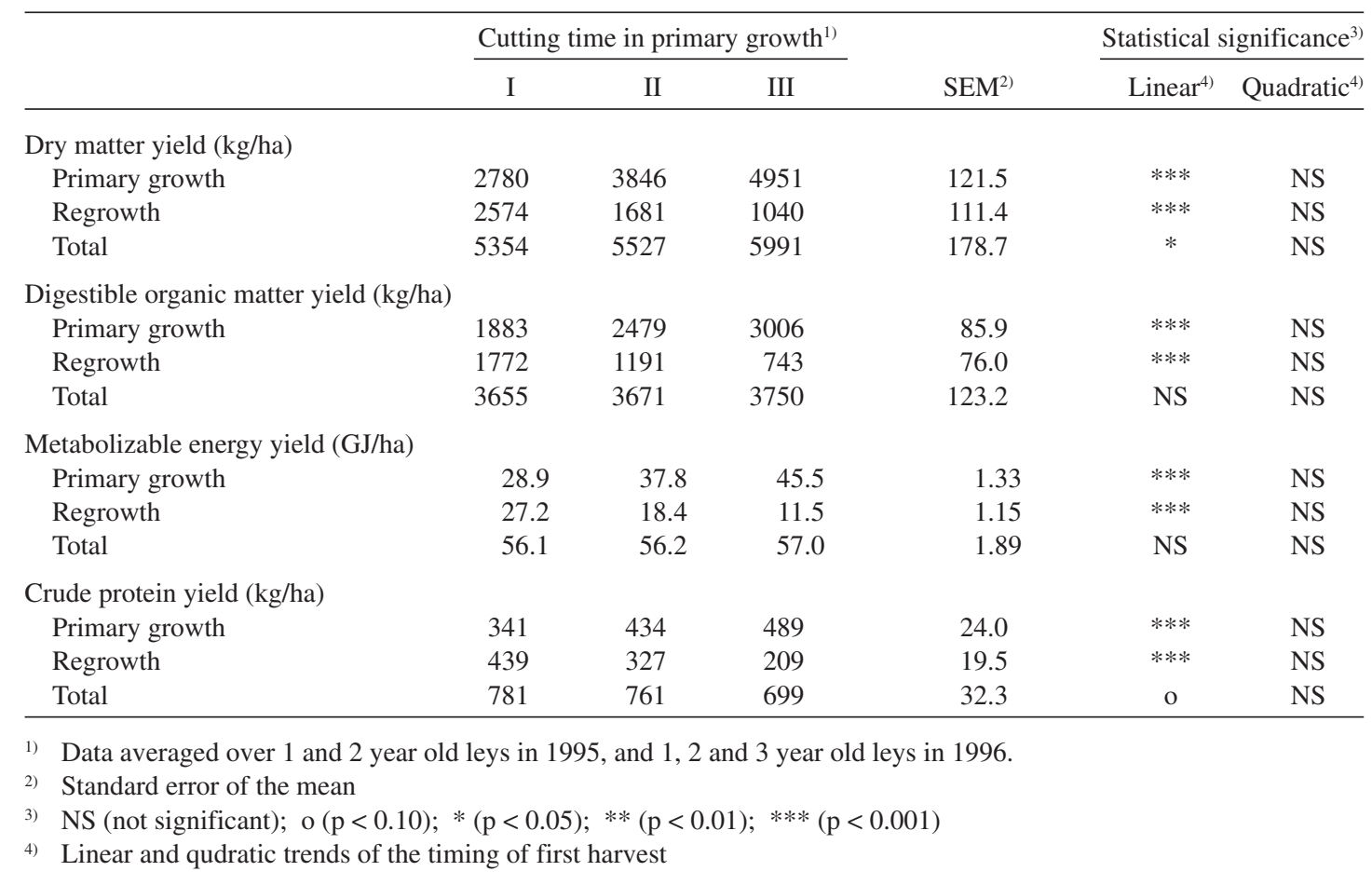

not affect the botanical composition of primary growths and regrowths. The difference in botanical composition between primary growth and regrowth was remarkable especially in 1995 (Figure 1a and 1b), when the proportion of red clover was only 0.098 in primary growth but 0.747 in regrowth. Corresponding values in 1996 were 0.471 and 0.673 , respectively. Although meadow fescue was included in the seed mixture, very little (on average 0.073 ) was found in harvested herbage. The red clover content of weighted total yield decreased as harvest of first cut was postponed (Figure 1c; 0.46, 0.43 and 0.35 for harvests I, II and III, respectively, $\left.\mathrm{P}_{\mathrm{L}}<0.01\right)$. Age of the ley had only minor effects on the proportion of red clover in total yield [0.26 and 0.30 for one and two year old leys in 1995 $(\mathrm{P}<0.10)$ and $0.59,0.51$ and 0.55 for one, two and three year old leys in $1996(\mathrm{P}>0.10)]$.
Advances in the development of timothy and red clover with postponed harvest in primary growth were clearly indicated by changes in the morphological composition of the plants (Table 3 ). Changes were slower in red clover. For example, proportion of leaves in the primary growth decreased 0.0043 units per day in red clover and 0.0080 units in timothy. Reciprocal effects were identified in regrowth, the extent of which were more profound for red clover (the proportion of leaves increased by 0.0099 units per day in red clover and by 0.0026 units in timothy).

Results from chemical analysis of leaf and stem fractions from the plants, reconstituted plants and reconstituted yields are presented in Table 4. Changes during primary growth were more rapid in timothy than red clover. The decline in D-value of timothy leaves $(1.0 \mathrm{~g} / \mathrm{kg}$ per 


\section{AGRICULTURAL AND FOOD SCIENCE IN FINLAND}

Rinne, M. \& Nykänen, A. Effects of harvesting strategy on organically grown leys

a)

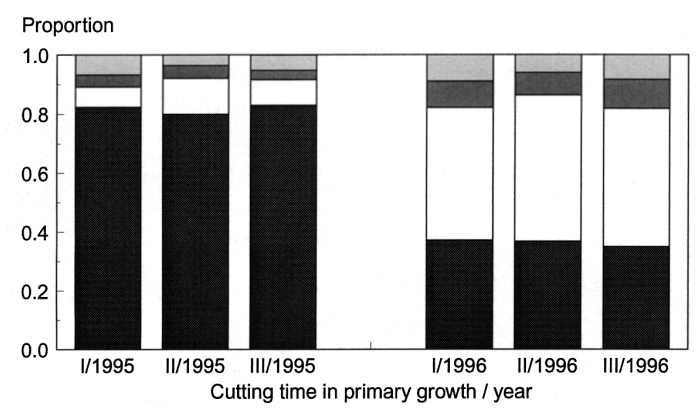

c)

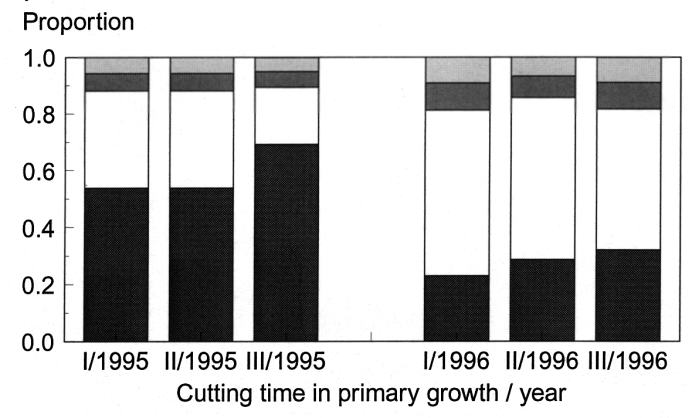

- Timothy $\square$ Red clover $\square$ Meadow fescue $\square$ Others b)

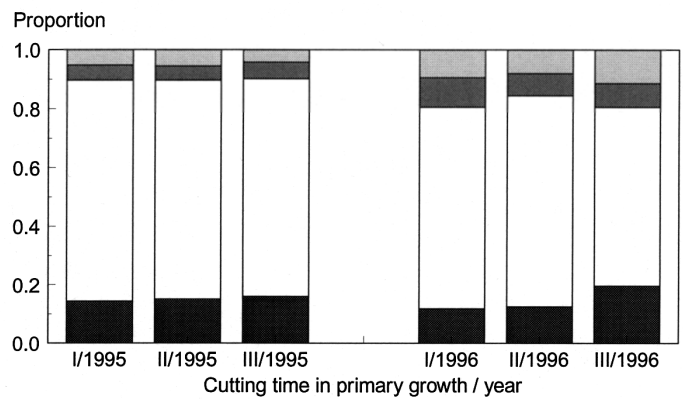

Fig. 1. The effect of cutting time of primary growth on botanical composition of primary growth (a), regrowth (b) and weighted total yield (c) of organically grown leys in 1995 and 1996.

Table 3. The effect of partition of growth time on morphological composition of timothy and red clover grown under organic conditions.

\begin{tabular}{|c|c|c|c|c|c|c|}
\hline & \multicolumn{3}{|c|}{ Cutting time in primary growth ${ }^{1)}$} & \multirow[b]{2}{*}{$\mathrm{SEM}^{2)}$} & \multicolumn{2}{|c|}{ Statistical significance $^{3}$} \\
\hline & I & II & III & & Linear & Quadratic \\
\hline \multicolumn{7}{|l|}{ Primary growth } \\
\hline \multicolumn{7}{|l|}{ Timothy } \\
\hline Leaves & 0.376 & 0.258 & 0.228 & 0.0135 & $* * *$ & * \\
\hline Stems & 0.582 & 0.651 & 0.672 & 0.0123 & $* * *$ & NS \\
\hline Inflorescenses & 0.042 & 0.092 & 0.100 & 0.0037 & $* * *$ & $* * *$ \\
\hline \multicolumn{7}{|l|}{ Red clover } \\
\hline Leaves & 0.452 & 0.426 & 0.367 & 0.0125 & $* * *$ & NS \\
\hline Stems & 0.549 & 0.574 & 0.624 & 0.0122 & $* * *$ & NS \\
\hline \multicolumn{7}{|l|}{ Regrowth } \\
\hline \multicolumn{7}{|l|}{ Timothy } \\
\hline Leaves & 0.907 & 0.950 & 0.957 & 0.0131 & * & NS \\
\hline Stems & 0.093 & 0.050 & 0.043 & 0.0103 & * & NS \\
\hline \multicolumn{7}{|l|}{ Red clover } \\
\hline Leaves & 0.395 & 0.520 & 0.601 & 0.0159 & $* * *$ & NS \\
\hline Stems & 0.537 & 0.435 & 0.389 & 0.0187 & $* * *$ & NS \\
\hline Inflorescenses & 0.068 & 0.045 & 0.011 & 0.0156 & * & NS \\
\hline
\end{tabular}

1) Data averaged over 1 and 2 year old leys in 1995, and 1, 2 and 3 year old leys in 1996.

2,3,4) see table 2 
Vol. 9 (2000): 121-134.

Table 4. Concentrations (g/kg dry matter) of ash, neutral detergent fibre (NDF), crude protein (CP), digestible organic matter (D-value), amino acids absorbed from the small intestine (AAT), protein balance in the rumen (PBV) and rate of digestion $\left(k_{d}, 1 / h\right.$; only for samples from 1995) in leaves, stems, reconstituted whole plants and reconstituted yields of organically grown leys (I, II and III represent the cutting time of the primary growth; each value is a mean of 5 observations except $\mathrm{k}_{\mathrm{d}}$, which is a mean of 2 observations).

\begin{tabular}{|c|c|c|c|c|c|c|c|}
\hline & Ash & $\mathrm{NDF}$ & $\mathrm{CP}$ & D-value & AAT & PBV & $\mathrm{k}_{\mathrm{d}}$ \\
\hline \multicolumn{8}{|c|}{ Primary growth } \\
\hline \multicolumn{8}{|c|}{ Timothy leaves } \\
\hline I & 69 & 529 & 145 & 704 & 93 & 35 & 0.0646 \\
\hline II & 70 & 550 & 141 & 695 & 92 & 33 & 0.0637 \\
\hline III & 76 & 554 & 139 & 683 & 90 & 33 & 0.0622 \\
\hline \multicolumn{8}{|c|}{ Timothy stems } \\
\hline I & 56 & 688 & 70 & 676 & 80 & -18 & 0.0490 \\
\hline II & 47 & 739 & 52 & 610 & 71 & -25 & 0.0424 \\
\hline III & 42 & 745 & 45 & 542 & 63 & -23 & 0.0423 \\
\hline \multicolumn{8}{|c|}{ Reconstituted timothy } \\
\hline I & 61 & 628 & 99 & 685 & 86 & 3 & 0.0542 \\
\hline I & 53 & 686 & 77 & 633 & 78 & -8 & 0.0474 \\
\hline III & 50 & 697 & 69 & 579 & 72 & -9 & 0.0459 \\
\hline \multicolumn{8}{|c|}{ Red clover leaves } \\
\hline I & 90 & 301 & 324 & 729 & 117 & 120 & 0.0680 \\
\hline II & 88 & 339 & 295 & 718 & 112 & 99 & 0.0710 \\
\hline III & 89 & 320 & 278 & 710 & 109 & 87 & 0.0677 \\
\hline \multicolumn{8}{|c|}{ Red clover stems } \\
\hline I & 105 & 377 & 137 & 702 & 90 & -18 & 0.0769 \\
\hline II & 86 & 443 & 105 & 672 & 83 & -37 & 0.0756 \\
\hline III & 71 & 487 & 92 & 633 & 78 & -41 & 0.0760 \\
\hline \multicolumn{8}{|c|}{ Reconstituted red clover } \\
\hline I & 98 & 344 & 221 & 714 & 102 & 44 & 0.0730 \\
\hline II & 86 & 401 & 186 & 690 & 96 & 20 & 0.0739 \\
\hline III & 78 & 425 & 161 & 662 & 90 & 5 & 0.0730 \\
\hline \multicolumn{8}{|c|}{ Reconstituted yield of total primary growth } \\
\hline I & 72 & $543^{\circ}-1-2 \cdot(-2)$ & 135 & 691 & 92 & 18 & 0.0558 \\
\hline II & 64 & 587 & 117 & 650 & 85 & 7 & 0.0511 \\
\hline III & 57 & 605 & 98 & 606 & 79 & 2 & 0.0487 \\
\hline \multicolumn{8}{|l|}{ Regrowth } \\
\hline \multicolumn{8}{|c|}{ Timothy leaves } \\
\hline I & 74 & 573 & 128 & 719 & 92 & 22 & 0.0655 \\
\hline II & 73 & 557 & 127 & 723 & 92 & 22 & 0.0685 \\
\hline III & 72 & 534 & 130 & 729 & 93 & 23 & 0.0677 \\
\hline \multicolumn{8}{|c|}{ Red clover leaves } \\
\hline I & 98 & 294 & 283 & 712 & 110 & 91 & 0.0663 \\
\hline II & 96 & 305 & 289 & 711 & 111 & 96 & 0.0722 \\
\hline III & 97 & 296 & 290 & 713 & 111 & 96 & 0.0713 \\
\hline \multicolumn{8}{|c|}{ Red clover stems } \\
\hline I & 73 & 447 & 104 & 665 & 83 & -38 & 0.0810 \\
\hline II & 82 & 409 & 106 & 696 & 86 & -41 & 0.0809 \\
\hline III & 92 & 388 & 116 & 704 & 88 & -35 & 0.0789 \\
\hline \multicolumn{8}{|c|}{ Reconstituted red clover } \\
\hline I & 84 & 383 & 179 & 683 & 94 & 15 & 0.0736 \\
\hline II & 90 & 350 & 207 & 706 & 100 & 34 & 0.0763 \\
\hline III & 95 & 331 & 221 & 710 & 102 & 44 & 0.0743 \\
\hline \multicolumn{8}{|c|}{ Reconstituted yield of total regrowth } \\
\hline I & 83 & 412 & 171 & 689 & 94 & 17 & 0.0722 \\
\hline II & 87 & 383 & 195 & 709 & 99 & 32 & 0.0749 \\
\hline III & 90 & 375 & 202 & 714 & 100 & 41 & 0.0731 \\
\hline \multicolumn{8}{|c|}{ Reconstituted total yield } \\
\hline I & 76 & 480 & 154 & 690 & 93 & 18 & 0.0623 \\
\hline II & 72 & 512 & 147 & 673 & 90 & 7 & 0.0576 \\
\hline III & 64 & 548 & 129 & 631 & 83 & 2 & 0.0527 \\
\hline
\end{tabular}




\section{AGRICULTURAL AND FOOD SCIENCE IN FINLAND}

Rinne, M. \& Nykänen, A. Effects of harvesting strategy on organically grown leys

day) was less than that of timothy stems $(6.9 \mathrm{~g} /$ $\mathrm{kg}$ per day). The respective values of decline in D-value per day for red clover were $0.8 \mathrm{~g} / \mathrm{kg}$ in leaves and $3.5 \mathrm{~g} / \mathrm{kg}$ in stems. These changes resulted in a daily decline in D-value of 5.6 and $2.6 \mathrm{~g} / \mathrm{kg}$ for reconstituted timothy and red clover, respectively.

The nutritional value of timothy was lower than that of red clover in the primary cut. On average D-value and CP content were 634 and $82 \mathrm{~g} / \mathrm{kg}$ DM in timothy and 689 and $200 \mathrm{~g} / \mathrm{kg}$ $\mathrm{DM}$ in red clover. Because the proportion of red clover was small in the primary growth, the quality of the reconstituted primary yield was high only for the first harvest date. In the regrowth, differences in the nutritional quality between plant species were smaller. On average D-value and $\mathrm{CP}$ content were 725 and $128 \mathrm{~g} / \mathrm{kg} \mathrm{DM}$ in timothy and 699 and $204 \mathrm{~g} / \mathrm{kg}$ DM in red clover. Residual effects of date of harvest in primary growth were lower for the regrowth than differences found in the quality of primary growth. Since primary growth represented the majority of herbage harvested, the marked decline in timothy quality in primary growth was discernible even in the reconstituted total yield for the whole growing season as the weighted D-value for harvests I, II and III was 690, 673 and $631 \mathrm{~g} / \mathrm{kg}$ DM, respectively.

Timothy leaves were digested faster than stems ( 0.0654 vs. 0.0446 per h) while the reverse was true for red clover (0.0694 vs. 0.0782 per h). In general red clover was digested faster than timothy. Developmental effects on $\mathrm{k}_{\mathrm{d}}$ of morphological fractions were minor and therefore clear trends in reconstituted timothy were primarily due to changes in the proportion of different morphological fractions.

\section{Discussion}

\section{Herbage production}

Compromises in total DM yield were less than $700 \mathrm{~kg} / \mathrm{ha}$ caused by early harvesting of prima- ry growth. Similar results were obtained when timing of first cut was manipulated in a 3-cut system (Syrjälä and Ojala 1978) or in a system where the number of cuts varied from 4 to 6 depending on the timing of the first cut (Frame 1987). Differences between early and late cuts of the primary growth were diminished to less than $100 \mathrm{~kg} / \mathrm{ha}$ when compared on the basis of digestible OM yield.

Digestible OM yield of forage is a more valid criterion than DM yield when animal production is the ultimate goal of plant production, but this parameter also has limitations. High digestible OM yield may be achieved in situations of large DM yield even though the concentration of digestible nutrients may be low. The critical factor in terms of animal nutrition is the concentration of digestible nutrients due to limited intake capacity of animals (Van Soest 1994). On grass silage based diets, a D-value around 700 $\mathrm{g} / \mathrm{kg}$ can be recommended for milk production (Rinne et al. 1999a).

In mixed leys, the proportion of red clover is generally lower in primary growth than in regrowth ( 0.40 vs. 0.60 without $\mathrm{N}$ fertilization reported by Hakkola and Nykänen-Kurki 1994). In cases of severe overwintering problems such as in 1995 in the present experiment, the proportion of red clover may be very low in primary growth. Postponed harvest of primary growth did not increase the proportion of red clover for either year in the current study. Frame (1987) found that the proportion of white clover decreased with postponed harvest when grown with ryegrass receiving either 0 or $80 \mathrm{~kg} \mathrm{~N}$ per hectare. In the two year trial of Fagerberg and Ekbohm (1995), the proportion of red clover increased in the first year with postponed harvest of primary growth, but decreased in the second year. A stable but substantially higher red clover content was obtained in regrowth.

In practical feeding situations, it is often only possible to feed one silage at a time. If silages harvested from primary growth which consist mainly of grasses of low digestibility and low intake potential, and regrowth which consist mainly of legumes with high digestibility and 
Vol. 9 (2000): 121-134.

intake potential are to be used, formulation of balanced rations to livestock becomes more difficult. Benefits in the form of increased proportion of clover in herbage DM with postponed harvest of primary growth seem unrealistic.

\section{Development of digestibility}

Decrease of digestibility with advancing development of plants in primary growth is well established. Reported values ( $\mathrm{g} / \mathrm{kg}$ per day) for timothy vs. red clover (6.0 vs. 3.3, Salo et al. 1975; 5.1 vs. 1.7, Hakkola and Nykänen-Kurki 1994 (recalculated from ME content estimated according to the Menke gas production method); 3.1 vs. 1.9, Fagerberg and Ekbohm 1995 (recalculated from ME content estimated using Near Infrared Spectroscopy) indicate that the decline is more rapid for grasses than for legumes, a finding consistent with the current data.

In several data sets, digestibility of grasses was higher than that of legumes early in the growing period (Salo et al. 1975, Hakkola and Nykänen-Kurki 1994, Fagerberg and Ekbohm 1995). This observation can also be deduced from the current results by extrapolation of regression analysis presented in Figure 2a. Around typical harvest times, no great differences between species may be found. However, the slower rate of decline of red clover allows more flexibility in harvesting strategy provided that red clover represents a significant proportion of herbage DM.

Only small differences were found in the rate of decline in digestibility, when different species or varieties of temperate perennial grasses were compared (Salo et al. 1975, Salo 1978, Hides et al. 1983, Huokuna and Hakkola 1984, Cherney et al. 1993). However, no direct comparisons of organic and conventional production could be found in the literature. The $\mathrm{N}$ supply to the grasses may be lower in organic farming, particularly in cases of low legume persistence. This situation was evident in our data in 1995 , which resulted in very low CP contents of timothy.
Several studies have indicated that the level of $\mathrm{N}$ fertilization has only minimal effects on grass digestibility, despite increases in CP content (Huokuna and Hakkola 1984, Fagerberg and Ekbohm 1995). Salo (1978) observed no differences in the daily decline in digestibility of perennial grasses $(11.6,11.8$ and $11.1 \mathrm{~g} / \mathrm{kg}$ per day when plots were fertilized with 0,50 and $100 \mathrm{~kg}$ $\mathrm{N} /$ ha, respectively). However, Bélanger and McQueen (1998) observed a low rate of decline of $2.3 \mathrm{~g} / \mathrm{kg}$ in $\mathrm{N}$ deficient grass $(0 \mathrm{~N})$, but clearly higher rates of $5.5,4.6$ and $4.8 \mathrm{~g} / \mathrm{kg}$ in grasses receiving 70,140 and $210 \mathrm{~kg} \mathrm{~N} / \mathrm{ha}$, respectively. The slow decline in digestibility of unfertilized grass was mainly explained by a greater proportion of leaves in herbage DM (Bélanger and McQueen 1998). In a later study, Bélanger and McQueen (1999) concentrated on the digestibility development of timothy leaf and stem fractions under varying $\mathrm{N}$ nutrition. Leaf digestibility decreased slightly early in the growing season in response to $\mathrm{N}$ deficiency, but differences in stem digestibility were not found.

The decline in forage digestibility may not always be linear with respect to time (Poutiainen and Rinne 1971, Rinne et al. 1997, 1999b). Sanderson and Wedin (1989) and Bélanger and McQueen (1998) presented the development of digestibility of plants in relation to their phenological development. Estimates of herbage quality were accurate, but the use of phenological indexes is laborious and unsuitable for application on a farm level. Cumulative temperature appears to be a reasonably good predictor of plant development in primary growth at least under Finnish conditions (Pulli 1980, Huokuna and Hakkola 1984, Rinne et al. 1999b). Furthermore, information derived from meteorological measurements reduces labour requirements compared to phenological analysis and therefore represents a tool with great potential for practical application.

In the current experiment, the decline in digestibility was linear with respect to time, but was subject to large between-year variations (Figure 2a). This variation can be decreased by presenting $\mathrm{D}$-values in relation to cumulative 


\section{AGRICULTURAL AND FOOD SCIENCE IN FINLAND}

Rinne, M. \& Nykänen, A. Effects of harvesting strategy on organically grown leys

a)

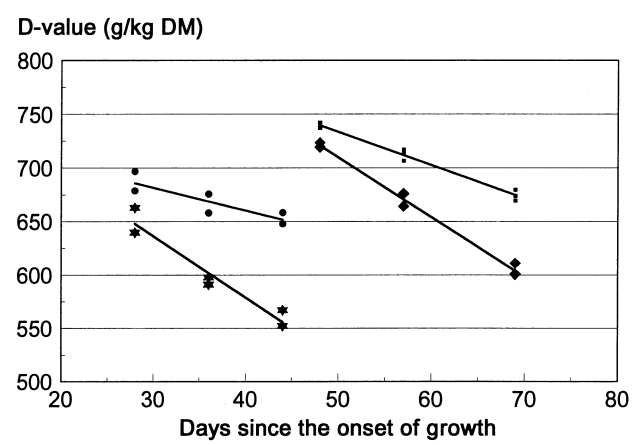

c)

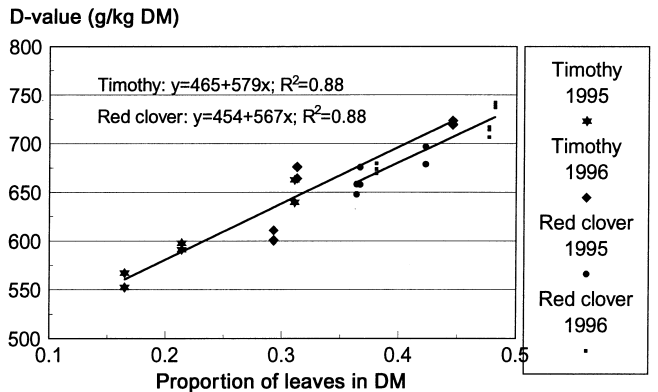

temperature and the relationship still remains linear (Figure 2b). A good prediction can also be derived based on the proportion of leaves in total plant DM (Figure 2c).

The clear decrease in the proportion of leaves appears to have accelerated the decline in timothy quality in primary growth whereas the high proportion of leaves probably contributed to the slower development in the regrowth. The slower decline in digestibility of leaves than stems with advances in grass development is well documented (Terry and Tilley 1964, Davies 1976, Hides et al. 1983, Sanderson and Wedin 1989, Bélanger and McQueen 1999). Digestibility of stems may be even higher than that of leaves at early stages of development, but around the common harvest time, digestibility of stems is clearly lower. In the data sets of Terry and Tilley (1964) and Sanderson and Wedin (1989), legumes were included. The development of lucerne exhibited a similar pattern to that described for grasses. The digestibility development of red b)

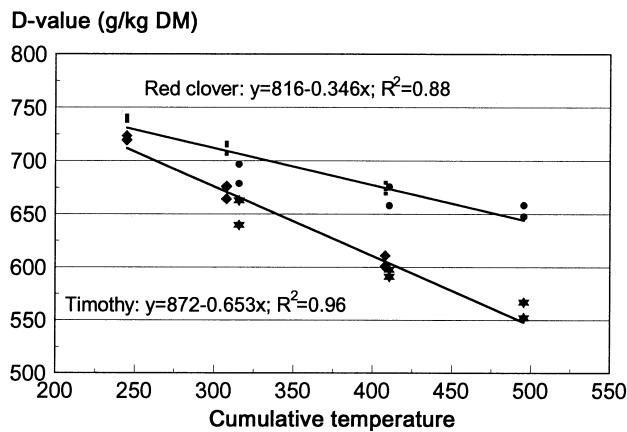

Fig. 2. Timothy and red clover D-values in primary growth as functions of growth time in days since the onset of growth in the spring (a), cumulative temperature (b) and proportion of leaves in dry matter (DM; c) in 1995 and 1996.

clover was only studied by Sanderson and Wedin (1989). The rate of decline in digestibility was greater in stems than leaves, but the digestibility of leaves remained lower than that of stems during the total observation period.

Declines in digestibility of ley regrowths is slower than that of primary growth (Syrjälä and Ojala 1978, Pulli 1980, Huokuna and Hakkola 1984, Bélanger and McQueen 1998, 1999). Due to higher DM yield and larger variations in primary growth quality, the effects of postponed harvest of primary growth were even discernible in the weighted composition of total yield. This was also noted by Syrjälä and Ojala (1978) and Frame (1987) using similar experimental designs.

\section{Consequences on animal feeding}

Inclusion of red clover in forage fed to dairy cows has resulted in higher milk production com- 
Vol. 9 (2000): 121-134.

\section{D-value (g/kg DM)}

Fig. 3. Correlations between Dvalue and rate of digestion $\left(\mathrm{k}_{\mathrm{d}}\right)$ of leaves and stems of red clover and timothy contained in primary growth and regrowth in 1995.

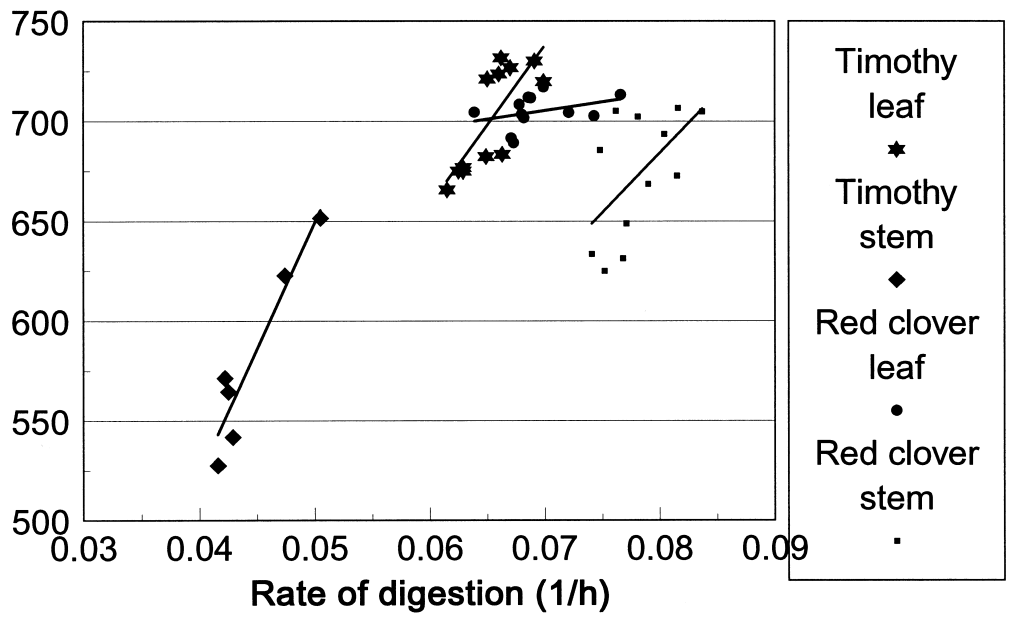

pared to silage prepared entirely from grasses (Thomas et al. 1985, Randby 1992, Heikkilä et al. 1996). In all cases, the intake of silage containing red clover was greater than that of pure grass silage. Increasing digestibility of forage is generally associated with increased intake (Van Soest 1994), but in previously cited studies, differences in forage digestibilities were small. Legumes seem to have properties other than high digestibility that contribute to a high intake potential.

The NDF concentration of legumes is lower than that of grasses, but the concentration of lignin is higher in legumes (Van Soest 1994). Possible intake promoting characteristics of legumes have been attributed to faster rates of digestion, passage and particle breakdown in the rumen (Smith et al. 1972, Grenet 1989, Van Soest 1994). These properties contribute to faster clearance of digesta from the rumen thus alleviating the constraint of physical fill on feed intake (Van Soest 1994). Higher $\mathrm{k}_{\mathrm{d}}$ of red clover compared to timothy was also observed in the current study. Although $\mathrm{k}_{\mathrm{d}}$ and digestibility were correlated, red clover fractions, primarily stems, had higher $\mathrm{k}_{\mathrm{d}}$ coefficients than timothy fractions of the same digestibility (Fig. 3).

Legumes are generally higher in $\mathrm{CP}$ than grasses. Responses to increased protein supplementation appear to be independent of grass silage $\mathrm{CP}$ content irrespective of the methods used for its manipulation such as $\mathrm{N}$ application rates (Shingfield et al. 1999) or harvest date (Rinne et al. 1999a). In the present study, the contents of AAT and PBV were lower for timothy relative to red clover. Information concerning the true protein value of grass $v s$. legume forages verified by animal production responses is limited. Heikkilä et al. (1996) reported similar milk production responses to protein supplementation with silage containing clover compared to pure grass silage indicating that responses were not limited by the inclusion of legumes.

Ease of indoor feeding of dairy cows would be improved, if forages harvested during summer have similar D-values. In organic production, the D-value should be relatively high due to the limitations in concentrate feeding (European Union 1999). These goals are best achieved when the primary growth of leys is harvested relatively early. If however, low D-value forage is produced due to postponed harvest of primary growth, concentrate intake must be increased to maintain milk production or otherwise a decrease in milk production has to be accepted (Rinne et al. 1999a). 


\section{AGRICULTURAL AND FOOD SCIENCE IN FINLAND}

Rinne, M. \& Nykänen, A. Effects of harvesting strategy on organically grown leys

\section{Conclusions}

The nutritional quality of both timothy and red clover decreased with postponed harvest of primary growth, but the extent of decline was greater for timothy. However, later harvesting resulted in higher DM yields. Reciprocal residual effects in the regrowth were less profound. If the aim of forage production is to produce feed for intensive animal production, primary growths should be harvested early, because the poor quality of primary growth influenced the quality of forage harvested across both growth periods. Cumulative temperature was a good predictor of herbage D-value in primary growth and it could be used to developed a practical application assisting in the choice of a correct harvesting time.

Acknowledgements. We appreciate the contribution of Seppo Ahvenjärvi for digestion kinetics analysis.

\section{References}

Bélanger, G. \& McQueen, R.E. 1998. Analysis of the nutritive value of timothy grown with varying $\mathrm{N}$ nutrition. Grass and Forage Science 53: 109-119.

- \& McQueen, R.E. 1999. Leaf and stem nutritive value of timothy grown with varying $N$ nutrition in spring and summer. Canadian Journal of Plant Science 79: 223-229.

Cherney, D.J.R., Cherney, J.H. \& Lucey, R.F. 1993. In vitro digestion kinetics and quality of perennial grasses as influenced by forage maturity. Journal of Dairy Science 76: 790-797.

Davies, I. 1976. Developmental characteristics of grass varieties in relation to their herbage production. 1 . An analysis of high-digestibility varieties of Dactylis glomerata at three stages of development. Journal of Agricultural Science, Cambridge 87: 25-32.

European Union 1999. European Union Official Journal L 222, 24 August 1999.

Fagerberg, B. \& Ekbohm, G. 1995. Variation in clover content and in nutritional value of grass-clover leys. In: Crop Production Science 23. Department of Crop Production Science, Swedish University of Agricultural Sciences, Uppsala, Sweden. 46 p.

Frame, J. 1987. The effect of strategic fertilizer nitrogen and date of primary harvest on the productivity of a perennial ryegrass/white clover sward. Grass and Forage Science 42: 33-42.

Friedel, K. 1990. Die Schätzung des energetischen Futterwertes von Grobfutter mit Hilfe einer Cellulasemethode. Wissenschaftliche Zeitung Universitet Rostock, N-Reihe 39: 78-86.

Grenet, E. 1989. A comparison of the digestion and reduction in particle size of lucerne hay (Medicago sativa) and Italian ryegrass hay (Lolium italicum) in the ovine digestive tract. British Journal of Nutrition 62: 493-507.

Hakkola, H. \& Nykänen-Kurki, P. 1994. Effect of nitrogen fertilization and cutting time on the quality and variable cost of red clover and timothy herbage produc- tion. In: Mannetje, L. 't \& Frame, J. (eds.). Grassland and Society. Proceedings of the 15th General Meeting of European Grassland Federation, Wageningen, The Netherlands, June 6-9, 1994. p. 105-108.

Heikkilä, T., Toivonen, V. \& Mela, T. 1996. Effects of red clover-grass, grass and annual ryegrass silages with two concentrate protein levels on milk production. In: Parente, G. et al. (eds.). Grassland and Land Use Systems. Proceedings of the 16th General Meeting of European Grassland Federation, Grado (Gorizia), Italy, September 15-19, 1996. p. 447-450.

Hides, D.H., Lovatt, J.A. \& Hayward, M.V. 1983. Influence of stage of maturity on the nutritive value of Italian ryegrasses. Grass and Forage Science 38: 3338.

Huhtanen, P. 1994. Forage influences on milk composition. Proceedings of the Nova Scotia forage conference; forage: seeding to feeding. The Nova Scotia Forage Council, Darthmouth, Nova Scotia. p. 144162.

Huokuna, E. \& Hakkola, H. 1984. Koiranheinän ja timotein kasvu ja rehuarvon muutokset säilörehuasteella. Tiedote 8/84. Maatalouden tutkimuskeskus, Jokioinen. 54 p.

Madsen, J., Hvelpund, T., Weisbjerg, M.R., Bertilsson, J., Olsson, I., Spörndly, R., Harstad, O.M., Volden, H., Tuori, M., Varvikko, T., Huhtanen, P. \& Olafsson, B.L. 1995. The AAT/PBV protein evaluation system for ruminants. A revision. Norwegian Journal of Agricultural Sciences, supplement no 19.

MAFF 1975. Energy allowances and feeding systems for ruminants. Technical Bulletin 33. Her Majesty's Stationery Office, London. 79 p.

Nykänen, A., Granstedt, A., Laine, A. \& Kunttu, S. 2000. The yields and clover contents of leys of different age in organic farming in Finland. Biological Agriculture and Horticulture (in press).

Ørskov, E.R. \& McDonald, I. 1979. The estimation of protein degradability in the rumen from incubation meas- 
Vol. 9 (2000): 121-134.

urements weighted according to rate of passage. Journal of Agricultural Science, Cambridge 92: 499503.

Poutiainen, E. \& Rinne, K. 1971. Korjuuasteen vaikutus säilörehun ravintoarvoon. Kehittyvä Maatalous 3: 15-28.

Pulli, S. 1980. Growth factors and management technique used in relation to the developmental rhythm and yield formation pattern of a pure grass stand. Journal of the Scientific Agricultural Society of Finland 52: 281330.

Randby, Å.T. 1992. Grass-clover silage for dairy cows. Proceedings of the 16th General Meeting of European Grassland Federation, Lahti, Finland, June 8-11, 1992. p. 272-275.

Rinne, M., Hellämäki, M., Nousiainen, J., Aura, E. \& Huhtanen, P. 1999b. Development of timothy during progressing growth and subsequent nutritional implications. Proceedings of the 12th International Silage Conference, Uppsala, Sweden, July 5-7, 1999. p. 166-167.

-, Jaakkola, S. \& Huhtanen, P. 1997. Grass maturity effects on cattle fed silage-based diets. 1. Organic matter digestion, rumen fermentation and nitrogen utilization. Animal Feed Science Technology 67: 117.

-, Jaakkola, S., Kaustell, K., Heikkilä, T. \& Huhtanen, P. 1999a. Silages harvested at different stages of grass growth $v$. concentrate foods as energy and protein sources in milk production. Animal Science 69: 251-263.

-, Nykänen, A. \& Ahvenjärvi, S. 1996. Maturity effects on botanical, morphological and chemical composition of organically grown leys. In: Parente, G. et al. (eds.). Grassland and Land Use Systems. Proceedings of the 16th General Meeting of European Grassland Federation, Grado (Gorizia), Italy, September 15-19, 1996. p. 575-578.

Robertson, J.B. \& Van Soest, P.J. 1981. The detergent system of analysis and its application to human foods. In: James, W.D.T. \& Theander, O. (eds.). The analyses of dietary fibre in foods. New York: MarcellDekker. p. 123-158.

Salo, M.-L. 1978. Kasvuasteen ja typpilannoituksen vaikutus säilörehunurmen rehuarvoon. Kehittyvä Maatalous 38: 3-10.

-, Nykänen, A. \& Sormunen, R. 1975. Composition, pepsin- $\mathrm{HCl}$ solubility and in vitro digestibility of forages at different growth stages. Journal of the Scientific Agricultural Society of Finland 47: 480-490.

Sanderson, M.A. \& Wedin, W.F. 1989. Phenological stage and herbage quality relationships in temperate grasses and legumes. Agronomy Journal 81: 864-869.

Shingfield, K.J., Jaakkola, S. \& Huhtanen, P. 1999. Comparison of the effects of dietary nitrogen supplements on the intake and milk production of Finnish Ayrshire dairy cows fed grass silage-based diets. Proceedings of the 12th International Silage Conference, Uppsala, Sweden, July 5-7, 1999. p. 159-160.

Smith, L.W., Goering, H.K. \& Gordon, C.H. 1972. Relationships of forage composition with rates of cell wall digestion and indigestibility of cell walls. Journal of Dairy Science 55: 1140-1147.

Syrjälä, L. \& Ojala, R. 1978. Kevät- ja syyssadosta eri kehitysasteilla valmistetun timoteisäilörehun ravintoarvo. Kehittyvä Maatalous 39: 36-49.

Terry, R.A. \& Tilley, J.M.A. 1964. The digestibility of the leaves and stems of perennial ryegrass, cocksfoot, timothy, tall fescue, lucerne and sainfoin, as measured by an in vitro procedure. Journal of the British Grassland Society 19: 363-372.

Theodorou, M.K., Williams, B.A., Dhanoa, M.S., McAlIan, A.B. \& France, J. 1994. A simple gas production method using a pressure transducer to determine the fermentation kinetics of ruminant feeds. Animal Feed Science and Technology 48: 185-197.

Thomas, C., Aston, K. \& Daley, S.R. 1985. Milk production from silage. 3. A comparison of red clover with grass silage. Animal Production 41: 23-31.

Tuori, M., Kaustell, K., Valaja, J., Aimonen, E., Saarisalo, E. \& Huhtanen, P. 1996. Rehutaulukot ja ruokintasuositukset (Feed tables and feeding recommendations, in Finnish). 2nd ed. Yliopistopaino, Helsinki. 99 p. +3 encl.

Van Soest, P.J. 1994. Nutritional ecology of the ruminant. 2nd ed. Cornell University Press, Ithaca, NY. 476 p. 
Rinne, M. \& Nykänen, A. Effects of harvesting strategy on organically grown leys

\title{
SELOSTUS
}

\section{Ensimmäisen sadon korjuuaika vaikuttaa timotein ja puna-apilan seosnurmen satoon ja rehuarvoon}

\author{
Marketta Rinne ja Arja Nykänen \\ Maatalouden tutkimuskeskus
}

Kasvuajan jakamisen vaikutuksia ensimmäisen ja toisen sadon kesken tutkittiin Juvalla kahtena vuonna luonnonmukaisesti viljeltyyn seosnurmeen, jonka pääkasvilajeja olivat timotei ja puna-apila. Ensimmäinen sato korjattiin kolmena eri aikana ja jälkikasvu samana päivänä elokuun lopussa. Kuiva-ainesato kasvoi ensimmäisessä sadossa $116 \mathrm{~kg} / \mathrm{ha}$ päivässä, kun korjuuta siirrettiin myöhäisemmäksi, mutta vastakkainen kehitys jälkikasvussa korvasi sen osittain. Korjuuaika ei vaikuttanut eri satojen kasvilajikoostumukseen, mutta puna-apilan osuus oli huomattavasti pienempi ensimmäisessä sadossa (28\%) toiseen satoon verrattuna $(71 \%)$. Koko kesän painotetussa nurmisadossa puna-apilan osuus pieneni 46:sta $35 \%$ :iin, kun ensimmäisen sadon korjuuta siirrettiin myöhäisemmäksi.
Sekä timotein että puna-apilan ravitsemuksellinen arvo huononi ensimmäisen sadon kasvun edetessä, mutta timotei huononi nopeammin kuin puna-apila. Sulavan orgaanisen aineen pitoisuus kuiva-aineessa pieneni timoteissä $5,6 \mathrm{~g} / \mathrm{kg}$ ja puna-apilassa $2,6 \mathrm{~g} / \mathrm{kg}$ päivässä. Muutokset jälkikasvussa olivat vastakkaisia. Ensimmäisen sadon kehityslinjat näkyivät kuitenkin selvästi myös koko kesän painotetussa sadossa, koska ensimmäisen sadon osuus koko sadosta oli keskimäärin $68 \%$ ja ensimmäisen sadon laatu vaihteli enemmän kuin toisen sadon. Tehoisan lämpösumman yhteys nurmikasvien D-arvoon alkukesällä oli selvä, joten lämpösumman hyödyntäminen nurmen korjuuajan valinnassa vaikuttaa mahdolliselta. 